\title{
Physical Conditions of Saline Water Intrusion into a Coastal Lagoon, Lake Shinji, Japan
}

\author{
Yu Ishitobi, Hiroshi Kamiya, Koji Yokoyama, Michio KumagaI \\ and Setsuo OKUDA
}

\begin{abstract}
In a coastal lagoon, Lake Shinji, saline water intrusion frequently occurs from the lower Ohashi River. Continuous observation of current velocity, salinity and water level in the Ohashi River revealed that intermittent intrusions takes place when diurnal periods of astronomical tide coincide with the rising stage of meteorological tides during a low discharge from the influent Hii River.

The dynamics of tidal currents and saline transport in the Ohashi River were examined by numerical simulation with a simplified onedimensional model using water level and salinity data from both river-channel ends. The calculated results reproduced well the observed time series of current velocity and salinity, though some disparity appeared under the two-layered structure. Related phenomena following the intrusion were described with respect to the formation of the stratified structure in Lake Shinji.
\end{abstract}

Key words : Lake Shinji, saline water intrusion, meteorological tide, one-dimensional model

\section{INTRODUCTION}

There have been many investigations into the intrusion of sea water into a coastal lagoon through a channel. The input of external energy such as an oceanic tide could essentially control the hydrodynamic processes of intru. sion. In a tidal condition with relatively large tidal amplitude, semi-diurnal variations with a range of $1.8 \mathrm{~m}$ during spring tide combined with low precipitation often initiate the intrusion (PICKRILL et al., 1981). In the case of a smaller astronomical tidal amplitude of less than $0.1 \mathrm{~m}$ per day, as seen in the coast of Western Australia, meteorological changes in water level due to variations in air pressure, wind, etc. range up to $0.5 \mathrm{~m}$ and play a large part in the intrusion (GABRIELSON and LUKATELICH, 1985).

The intrusion of sea water into a semi-enclosed lagoon usually assumes a two-layered structure which is pycnally more stable than that of the thermocline. In a eutrophic lagoon, the stratification due to an intrusion accelerates oxygen depletion in the bottom water and nutrient release from the sediments, which ultimately results in exerting a large influence on water quality. It is thus important to clarify the hydrodynamical mechanism of 
saline water intrusion into a eutrophic lagoon.

Lake Shinji, a shallow brackish lake, is now suffering from eutrophication. Monthly monitoring of water quality confirms instances of salinity stratification above the lake bottom. However, little investigation has been performed to clarify the mechanism underlying the formation and destruction of salinity stratification. We investigated the mechanism of saline water intrusion into Lake Shinji, which presumably induces the formation of the stratified structure.

The study of an irregular phenomenon induced by meteorological events requires long-term observation. We continuously measured current velocity and water quality near a point of saline water discharge into Lake Shinji. We also simulated water movement and salinity transportation at the entrance channel using a simple numerical method designed to predict an intrusion phenomenon using common hydraulic data, i.e., water level variations at both ends of the channel.

\section{STUDY AREA AND METHODS}

Figure 1 shows the locations of two brackish lakes, Lake Nakanoumi and Lake Shinji, in the San-in district of Japan. Lake Nakanoumi, contiguous to the Japan Sea, has a surface area of $88 \mathrm{~km}^{2}$ and a mean water depth of 5.4 $\mathrm{m}$. This lake is highly stratified with a stable halocline usually at a depth of about $4 \mathrm{~m}$. The salinity of the upper and lower layers is about $10 \%$ and 30 $\%$, respectively. A relatively high tidal water exchange occurs through the Sakai Channel which is $7.5 \mathrm{~km}$ long, $0.3 \mathrm{~km}$ wide and $10 \mathrm{~m}$ deep. The amplitudes of astronomical tidal variations in the Japan Sea decrease by only $25 \%$ in this lake (OHTAKe et al., 1984).

Lake Shinji is the inner lake with a surface area of $80 \mathrm{~km}^{2}$ and a mean depth of $4.5 \mathrm{~m}$. Its salinity ranges from 0.1 to $10 \%$, and a thin layer of

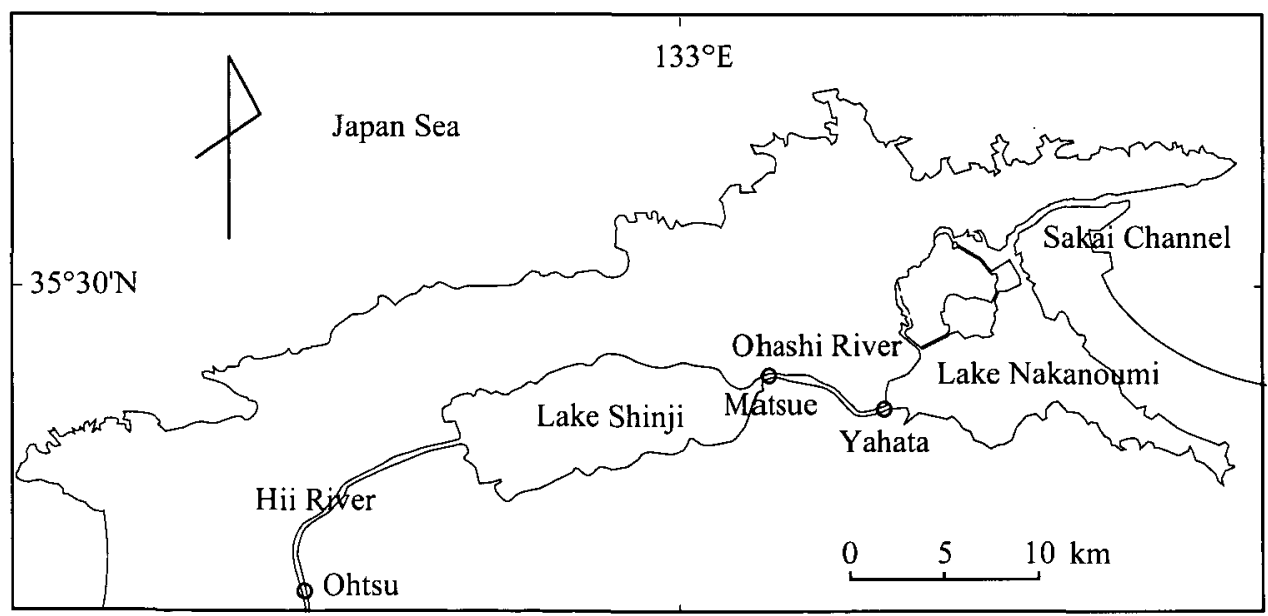

Fig. 1. Map of the coastal region containing the Hii River, Lake Shinji, the Ohashi River, Lake Nakanoumi and the Sakai Channel. 
highly saline water is sometimes found on the lake bottom. This suggests that the intermittent intrusion of saline water occurs from Lake Nakanoumi through the Ohashi River ( $7.5 \mathrm{~km}$ long, $0.1 \mathrm{~km}$ wide and $5 \mathrm{~m}$ deep) (Fig. 1). Fresh water is mainly supplied at the west end of Lake Shinji from the Hii River, which covers $70 \%$ of the total drainage basin of the lake.

Continuous observation was carried out near the uppermost point of the Ohashi River from 16 September to 16 October 1989 (at Matsue in Fig. 1). Figure 2 shows a mooring system of eight 3-dimensional current meters (ALEC Electronics Co., Ltd., model ACM-2 : accuracy of $\pm 1 \mathrm{~cm} \mathrm{sec}^{-1}$ ) for hourly measurements. An analysis barge was anchored on the left side to keep it clear of the shipping route, and salinity in the upper and lower layers was measured at two-hour intervals at water depths of $1.5 \mathrm{~m}$ and $5.0 \mathrm{~m}$. Supplementally, automatic water sampling was carried out at the same depths and intervals as those for salinity, and chemical analysis was conducted in the laboratory.

Hourly data on water level variations at the Yahata and Matsue tide stations on both ends of the Ohashi River were supplied by the River Bureau, Ministry of Construction. The Matsue tide station was located about $100 \mathrm{~m}$ upstream from the cross section of the observational site. The daily mean discharge of the Hii River at Ohtsu (Fig. 1) was obtained from data published by the River Bureau, Ministry of Construction (1991).

Numerical analyses of the tidal current and salinity transportation in the Ohashi River were carried out by the implicit finite-difference method based on a one-dimensional model. Computation was done using a personal computer (NEC 9801-FA) and basic programs which were made referring to Dronkers (1969) and KoJIMa and Machida (1987). The Gauss-Seider method was adopted for the solution of simultaneous equations. For the evaluation of the transportation of water mass and salinity, the cross section under the Matsue Ohashi Bridge was divided into three layers as shown by dashed lines in Figure 2.

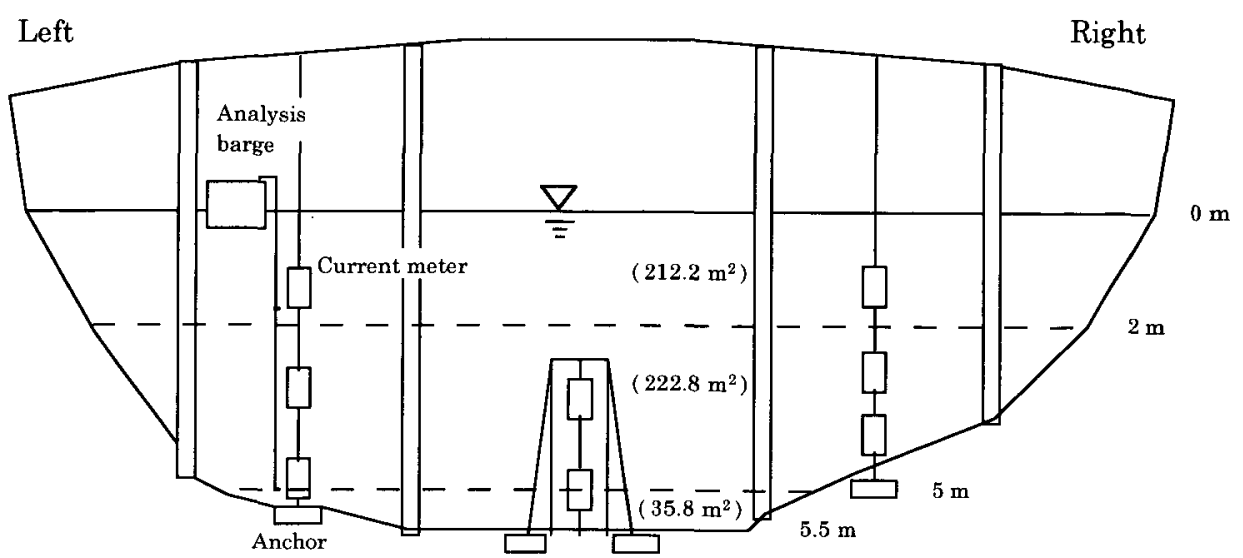

Fig. 2. Schematic illustration showing the measuring and sampling points. The upper, middle and lower layers are divided by dashed lines in the cross section under the Matsue Ohashi Bridge. 


\section{RESULTS AND DISCUSSION}

\section{Physical conditions of saline water intrusion}

It was difficult to obtain complete data on current velocity during the one-month observation. Two data sets, from the lower layer of the left side and from the upper layer of the right side in the cross section, were insufficient because of slack in the settling wire. Hence, we used only reliable data sets obtained by five current meters and a part of the data set from the lower layer of the central point for later analyses.

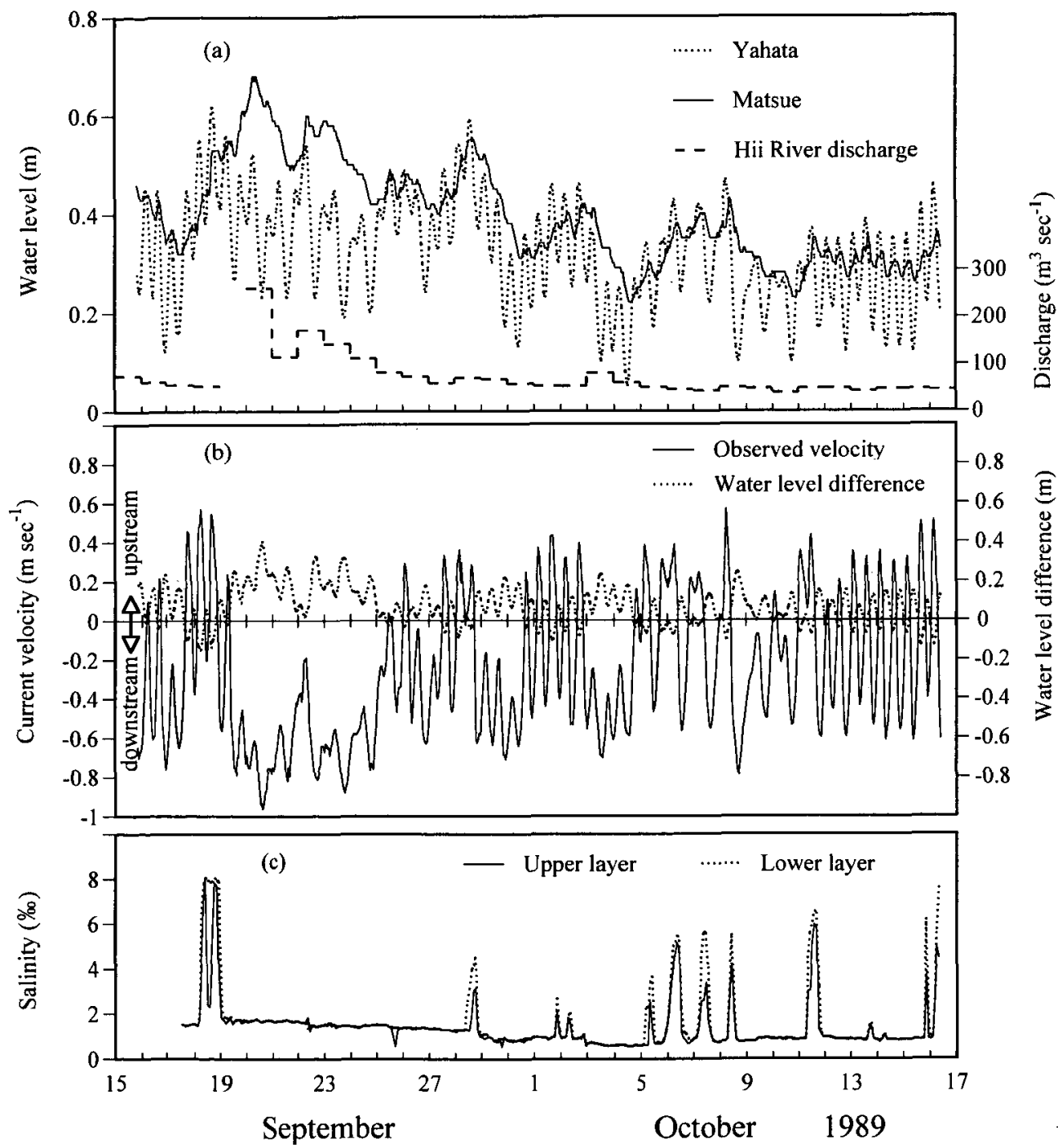

Fig. 3. Variations in (b) water level difference between Yahata and Matsue, and current velocity and (c) salinity for upper and lower layers at the Matsue Ohashi Bridge for one month. These are closely related to (a) the water level variations at Yahata and Matsue and to the water discharge from the influent Hii River. 
Figure 3a shows temporal variations in the water level at Yahata and Matsue and daily mean discharge of the Hii River at Ohtsu (see Fig. 1). Figures $3 \mathrm{~b}$ and $3 \mathrm{c}$ show temporal variations in current velocity in the middle layer of the left side, water level difference between Yahata and Matsue, and salinity in the upper and lower layers of the left side. The positive value in current velocity indicates the upstream flow, and the datum of water levels is the mean sea level of Tokyo Bay. Figures $3 \mathrm{~b}$ and $3 \mathrm{c}$ allow us to suppose the occurrence of intermittent intrusions of saline water into Lake Shinji because the observational point is near the sill at the entrance to Lake Shinji.

The water level variation at Yahata reflects the peculiarity of water level variations in Lake Nakanoumi. It involves an astronomical component with a period of $12.5 \mathrm{hrs}$ and a meteorological component which varies with non-periodicity for several days and has an amplitude comparable to the astronomical component. Meanwhile, in Lake Shinji, as shown by the water level variations at Matsue, the astronomical component diminishes. The residual meteorological component and the rise in water level by high discharge from the Hii River are noticeable.

Water movement in the Ohashi River seems to be determined by the relative difference in the water level at both ends. For the period of 20-24 September, the downstream current with a duration of more than 1 day appears due to the elevation of the water level in Lake Shinji by the high discharge from the Hii River (Fig. 3b). Even in this period, the variation in current velocity was negatively synchronized with the astronomical tidal cycle. During low discharge from the Hii River, the water level at Matsue was comparable to that at Yahata, though the amplitude of the former remained smaller than that of the latter. As a result, alternative currents appear during periods of semi-diurnal or diurnal tide, following the positive or negative water difference.

IsHITOBI et al. (1993) pointed out that, during the rising stage of a meteorological variation, the high water in the astronomical tidal cycle in Lake Nakanoumi largely exceeded the water level of Lake Shinji, provided the Hii River discharge was low. This water level condition would yield an upstream flow in the Ohashi River, which might in turn induce saline water intrusion into Lake Shinji. A typical example in which a meteorological tide results in an intrusion of saline water is described in estuaries around the Baltic Sea where the astronomical tide is very weak (JASINSKA, 1993).

However, intrusions do not always occur under the above meteorological tidal conditions at low discharge. As seen in Figure 3c, during the two meteorological rising stages of 1 to 3 October and 5 to 8 October, a larger increase in salinity was observed with a diurnal rather than as a semi-diurnal variation. When the water level of Lake Nakanoumi exceeded the level of Lake Shinji, it remained longer in the diurnal than in the semi-diurnal variation. This consequently ensured a relatively long time period of upstream flow and might have allowed for the transportation of the water mass from Lake Nakanoumi to Lake Shinji through the long channel of the Ohashi River, showing the increase in salinity in the later stage of upstream 
flow during a diurnal variation, as pointed out by IsHitoBi et al. (1989).

Therefore, it is concluded that the occasional coincidence of a diurnal period in an astronomical tide with a rising stage in the meteorological tide under low discharge conditions in the Hii River brings about the intermittent saline water intrusion into Lake Shinji. The combination of such an extraordinary condition as a major meteorological rise in the water level of Lake Nakanoumi induced by a typhoon together with no discharge from the Hii River owing to a long dry spell seems to accelerate the upstream flow and ultimately to induce the intrusion of saline water.

\section{Characteristics of the river current}

Figure 4 shows the correlation plots of current velocity in the middle layer of the left side versus the water level difference between Yahata and Matsue. The current velocity is seen to be proportional to the square root of the water level difference, especially in the ebb tidal region. This is similar to hydraulic currents due to the pressure gradient by the difference in water levels, a phenomenon commonly found in straits where different tidal movements prevail at the two ends (PUGH, 1987). Figure 4 also indicates another interesting phenomenon, i.e., that the water mass still moves when the difference in water levels is reduced to zero before the turn from ebb to flood tide and back again.

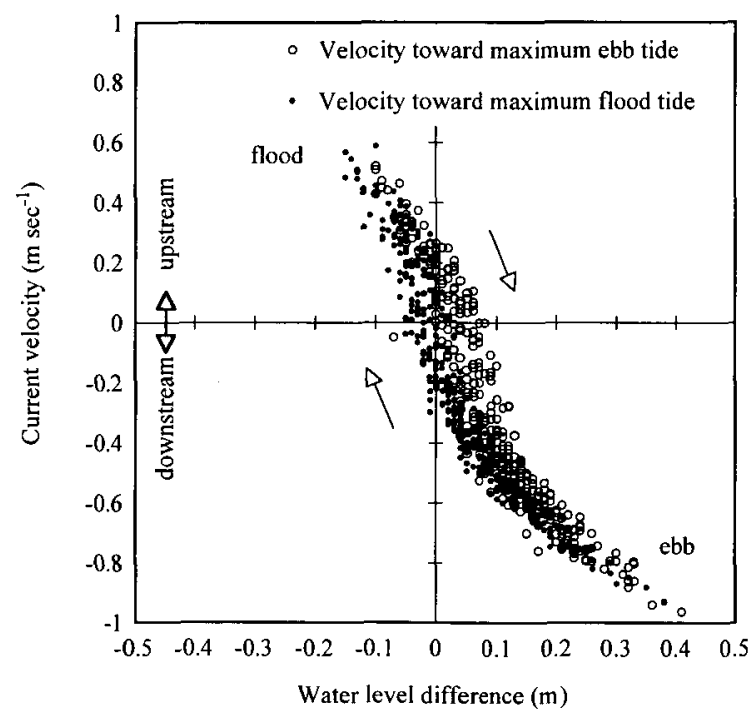

Fig. 4. Correlation plots of current velocity versus water level difference between the two ends of the Ohashi River. Open circles indicate velocity decreasing from maximum flood to maximum ebb tide, and solid circles indicate velocity increasing from maximum ebb to maximum flood tide. 
Table 1. Relationship of squared velocity to water level difference at the cross section under the Matsue Ohashi Bridge.

\begin{tabular}{llcc}
\hline \multicolumn{1}{c}{ Location } & Regression equation & Correlation Coeff. & N. of Sample \\
\hline Upper left & $u^{2}=1.51^{2}(\Delta h-0.008)$ & $0.949^{*}$ & 735 \\
Middle left & $u^{2}=1.47^{2}(\Delta h-0.002)$ & $0.957^{*}$ & 735 \\
Middle center & $u^{2}=1.72^{2}(\Delta h-0.004)$ & $0.949^{*}$ & 735 \\
Middle right & $u^{2}=1.63^{2}(\Delta h+0.006)$ & $0.955^{*}$ & 735 \\
Lower center & $u^{2}=1.21^{2}(\Delta h+0.004)$ & $0.911^{*}$ & 496 \\
Lower right & $u^{2}=1.55^{2}(\Delta h+0.005)$ & $0.955^{*}$ & 735 \\
\hline
\end{tabular}

$\left.u=(\mathrm{m} \mathrm{sec})^{-1}\right), \Delta h=(\mathrm{m}),{ }^{*}$ significant at the $0.1 \%$ level

Table 1 lists linear regression equations for six measuring points, based on the square root relationship,

$$
|u|=K \sqrt{ }|\Delta h-c|
$$

in which $u=$ current velocity, $K=$ water flux coefficient, $\Delta h=$ water level difference, and $c=$ a constant introduced for the calculation of regression equations. All relations are highly correlated at the $0.1 \%$ significance level. Each equation has similar $K$ and negligible $c$ as compared to $\Delta h$, which generally indicates that a homogeneous flow occurs within the cross section at the observational site during flood and ebb tides.

The water flux coefficient $K$ in Equation (1) is a convenient index of hydraulic characteristics such as the shear velocity of river flow. FUJII and NAGANAWA (1995) reported this coefficient to be $0.9 \mathrm{~m}^{1 / 2} \mathrm{sec}^{-1}$ for the Ohashi River. They obtained it by the numerical method using the semidiurnal part of the in situ record of water level changes in Lake Nakanoumi and Lake Shinji. For the present study, $K$ ranges from 1.21 to $1.72 \mathrm{~m}^{1 / 2}$ $\mathrm{sec}^{-1}$ (see Table 1). A similar value, $1.4 \mathrm{~m}^{1 / 2} \mathrm{sec}^{-1}$, is derived from the coefficient of Chézy, $57 \mathrm{~m}^{1 / 2} \mathrm{sec}^{-1}$, which was obtained in the later numerical computation.

Even if an appropriate water flux coefficient, $K$ was given and the water level difference, $\Delta h$ was known, Equation (1) could not provide the actual variation in current velocity, but only the mean velocity of the fluctuations in water level differences. Another numerical analysis on the current velocity is required to reproduce detailed water movement in this river.

\section{One-dimensional model in Ohashi River}

River current In a tidal river, the water motion can be considered primarily one-dimensional, even though there is a difference in density between salt and fresh water (DRONKERS, 1969). Along the river channel, choosing $\mathrm{x}$-axis in the upstream direction with $x_{0}$ at the lower end of the channel, the simplified equations of motion and continuity at time $t$ are :

$$
\begin{aligned}
& \partial u / \partial t+u \cdot \partial u / \partial x=-g \cdot \partial h / \partial x-g \cdot|u| u /\left(C^{2}\left(a_{0}+h\right)\right) \\
& \partial(A u) / \partial x+b \cdot \partial h / \partial t=0
\end{aligned}
$$


where $u=$ mean velocity in a cross section, $h=$ height of water level with respect to mean water level, $b=$ stream width, $A=b \cdot\left(a_{0}+h\right)$ where $a_{0}$ is equal to water depth, $C=$ coefficient of Chézy, and $g=$ acceleration due to gravity. The second term in the right side of Equation (2) indicates the friction resistance.

Table 2. Parameters used for one-dimensional computation.

\begin{tabular}{lcc}
\hline Section length & 1000 & $\mathrm{~m}$ \\
Section number & 8 & \\
Stream width & 85 & $\mathrm{~m}$ \\
Stream depth & 5.5 & $\mathrm{~m}$ \\
Time step (current velocity) & 60 & $\mathrm{sec}$ \\
$\quad$ (salinity transportation) & 600 & $\mathrm{sec}$ \\
Horizontal diffusion coefficient, $D_{x}$ in Eq. (6) & 1 & $\mathrm{~m}^{2} \mathrm{sec}^{-1}$ \\
Coefficient of Chézy, $C$ in Eq. (2) & 57 & $\mathrm{~m}^{1 / 2} \mathrm{sec}^{-1}$ \\
\hline
\end{tabular}

According to DronKers (1969), Equations (2) and (3) were converted into implicit difference-equations for current velocity, and a one dimensional calculation was carried out for a given $h$ at both ends as boundary conditions. The initial velocity was given as zero for all points. Parameters used for the computation of river current and salinity transportation are listed in Table 2. Following the section length adopted here, the locations of the Yahata tide station and the observational site for velocity and salinity at Matsue are consistent with the computation scheme. Here, the Matsue tide station is assumed to be upstream of the real site. It is also assumed that the cross section of the river is rectangular with a constant depth and stream width. In this computation scheme, the coefficient of Chézy, $C$, is empirically determined to be $57 \mathrm{~m}^{1 / 2} \mathrm{sec}^{-1}$, by which the calculated variations in velocity fit well with the observed variations.

The coefficient of Chézy gives the water flux coefficient, $K=1.4 \mathrm{~m}^{1 / 2} \mathrm{sec}^{-1}$ as indicated earlier, by comparing Equation (1) with the following transformed Chézy's equation,

$$
\mathrm{u}=C{ }^{-}(R / L) \cdot \sqrt{ } \Delta h
$$

in which $C \checkmark(R / L)$ corresponded to $K$ in Equation (1). Here, $C=$ coefficient of Chézy, $R$ (hydraulic mean depth) $=A / S$ ( $A$ : cross sectional area, $S$ : wetted perimeter), $L=$ length, and $\Delta h=$ water level difference between two end points.

Figure 5 shows the calculated velocity (open circle) at Matsue for the period of 16 September to 16 October 1989, compared with the observed one (solid line). The positive velocity indicates upstream flow. The calculated velocity shows good agreement with the observed one except for some minor points, e.g., at the former part of a flood tide from 20:00 on 6 October 1989, 


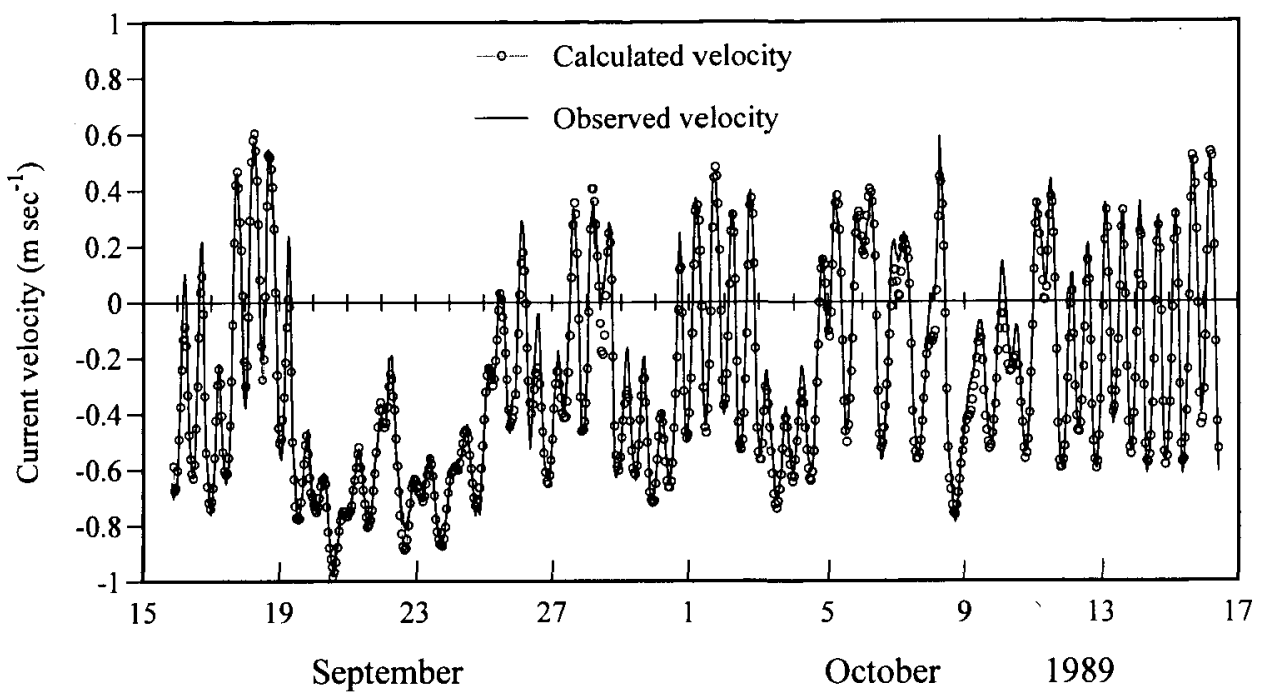

Fig. 5. Time series of the calculated current velocity shown by open circles at Matsue compared to the observed ones indicated by solid lines. The positive direction indicates upstream flow.

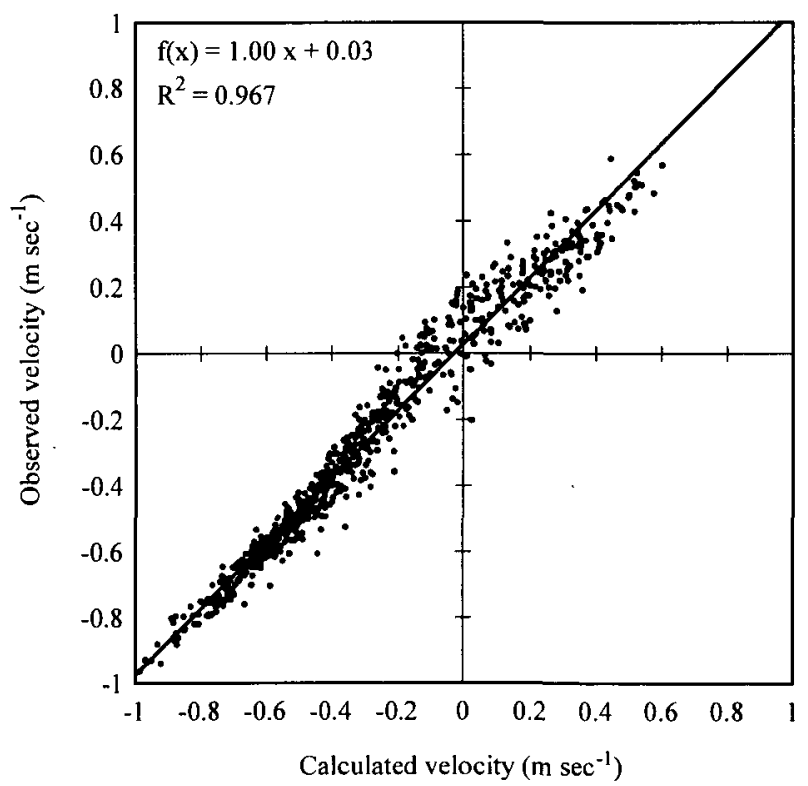

Fig. 6. Correlation plots of calculated current velocity versus the observed one at Matsue.

the calculated velocity was smaller than the observed one. The current velocity is largely affected by the small fluctuation around the zero water level difference. This might be one of the reasons for the above deviations.

Figure 6 shows the relation between the calculated and observed velocities. There is good linearity despite some scatter in the low-speed region. 
The regression equation from 734 samples is given as :

$$
\mathrm{V}(\text { obs. })=1.00 \cdot \mathrm{V}(\text { cal. })+0.03
$$

which gives the correlation coefficient $R$ of 0.983 with significance at the $0.1 \%$ level. The one-dimensional current computation seems to be satisfactory in spite of the fact that the difference in density between the two waters is neglected.

Salinity transportation Following the analysis of river current, a onedimensional computation for salinity transportation is attempted under the same scheme of the implicit finite-difference method, using weekly salinity values at Lake Nakanoumi and two hourly values at Lake Shinji estimated from the observed salinity at Matsue. The conservation equation of salinity at time $t$ is :

$$
\partial(S A) / \partial t+\partial(S Q) / \partial x=\partial / \partial x\left(D_{x} \cdot A \cdot \partial S / \partial x\right)
$$

in which $S=$ mean concentration of salinity, $Q=$ total discharge passing through a cross section and $D_{x}=$ horizontal diffusion coefficient.

Figure 7 shows the calculated variation at Matsue from 16 September to 16 October 1989 in comparison with the measured variations at the upper and lower layers. The calculated variation approximately agrees with the measured ones when the salinities at both layers are close. Meanwhile, it seems to trace the upper salinity rather than the lower one when the two-layered structure is predominant. UNCLES and STEPHENS (1993) report-

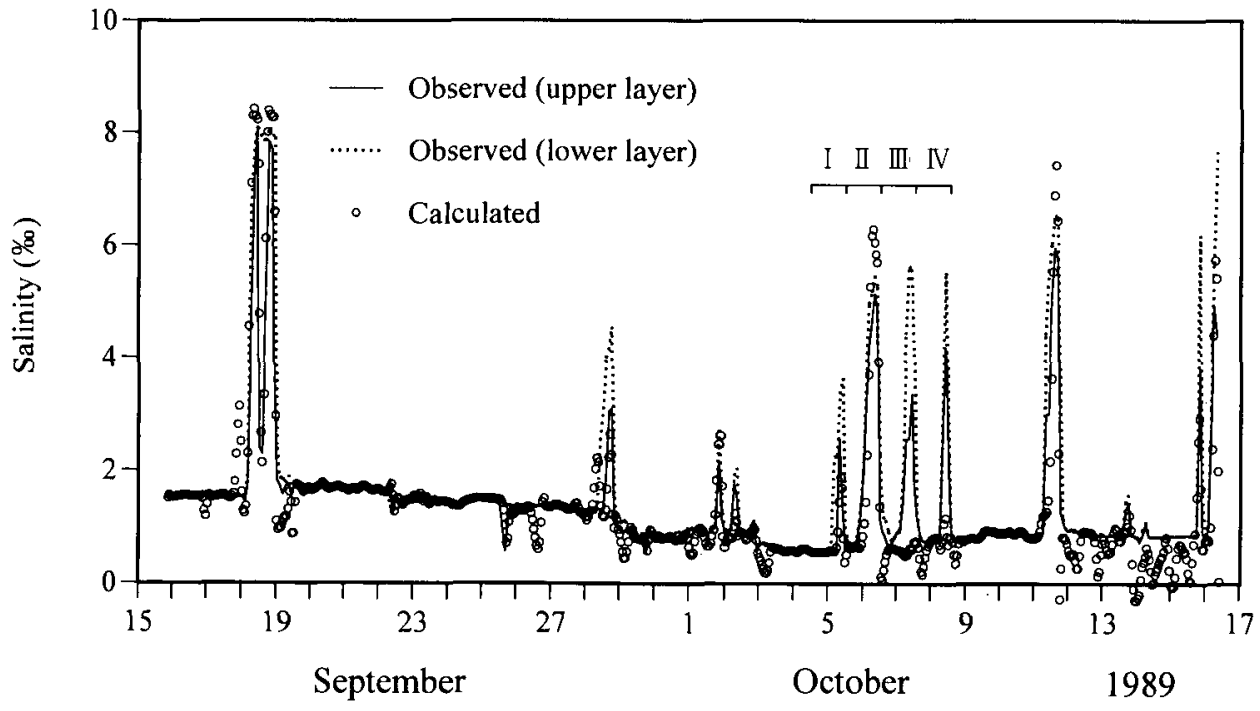

Fig. 7. Time series of calculated salinity shown by open circles at Matsue compared to the observed ones in the two layers. The time periods from I to IV indicate successive four diurnal cycles used for the summation of water mass passed through the cross section. 
ed that a pronounced salinity stratification occurred at neap tide during a higher runoff in the Tamar Estuary, which resembles the water movement from Lake Shinji flowing down through the upper layer at a small tidal amplitude.

The calculated oscillation in salinity seems to be anomalous for the period of 12 to 15 October 1989. This is attributed to a numerical reason due to the finite-difference method, in which salinity at a section end is determined using salinties at both sides of neighboring section ends. When a saline front which had reached the downstream side of a neighboring section end flowed back again, a lower salinity should have been obtained by subtracting the salinity of highly saline water at the downstream section end.

Two large increases on 7 and 8 October 1989 are not well reproduced. Since the calculated velocity was smaller than the observed one in the former part of the diurnal flood tide from 20:00 on 6 October (Fig. 5), the front of the water from Lake Nakanoumi should have moved upstream slowly and not have reached the Matsue site. This numerically lower location of the front might have caused the small increase in salinity on the next day in addition to a prediction of negative velocity at the former part of the next flood tide.

The one-dimensional model is suitable for vertically homogeneous circumstances but not for stratified ones in which the water masses of upper and lower layers move separately. Indeed, the two-layered structure was observed after the turn from flood to ebb tide at a small tidal amplitude. Except for the period of the turn, however, current velocities within the cross section were almost the same even at the passage of a saline front with a small decline. It was also reported that the tidal exchange was the dominant component responsible for an upward salt flux, based on 25-hr observation of the same point at Matsue (IsнITOBI et al., 1989). These findings imply the simple manner of water movement in which the saline water mass with a declining front flows up and down through the river. This is generally consistent with the one-dimensional model. Consequently, this simplified model seems to be applicable to the computation of salinty transportation.

Formation of stratified structure in Lake Shinji The water masses that have passed through the cross section at Matsue are separately summarized in Table 3 with respect to upstream and downstream directions and the ranges of salinity as determined by the measuring and numerical methods for the four successive diurnal cycles of 25 -hr covering intrusion events from 11:00 on 4 October to 14:00 on 8 October 1989 (Fig. 7). In this period, the salinity was about $0.5 \%$ for the water in Lake Shinji and about $6 \%$ for the upper layer water in Lake Nakanoumi. For the observed values of summation, the salinity data from the upper layer at Matsue are assumed to represent the water quality for the upper and middle layers of the cross section, while the data from the lower layer are supposed to indicate the water quality for the lower section. It is also assumed that the velocity from the middle layer of the left side is that for the upper and middle sections, 
Table 3. Water mass $\left(\mathrm{x} 10^{6} \mathrm{~m}^{3}\right)$ passed through the cross section in four successive diurnal cycles from 11:00 on 4 October to 14:00 on 8 October 1989 (see Fig. 7).

\begin{tabular}{|c|c|c|c|c|c|c|c|c|c|}
\hline & \multicolumn{4}{|c|}{ Observed } & \multicolumn{4}{|c|}{ Calculated } \\
\hline & & Total & $<1.0 \%$ & $1.0 \%-4.0 \%$ & $>4.0 \%$ & Total & $<1.0 \%$ & $1.0 \%-4.0 \%$ & $>4.0 \%$ \\
\hline \multirow[t]{2}{*}{ I } & Upstream & 3.93 & ( 2.88 & 1.05 & -1 & 3.41 & ( 2.66 & 0.75 & - ) \\
\hline & Downstream & -5.85 & $(-5.02$ & -0.83 & -1 & -6.62 & $(-5.78$ & -0.84 & -1 \\
\hline \multirow[t]{2}{*}{ II } & Upstream & 6.90 & ( 1.90 & 2.20 & $2.80)$ & 6.94 & ( 2.39 & 1.39 & 3.16) \\
\hline & Downstream & -4.64 & $(-2.80$ & -1.57 & $-0.27)$ & -4.86 & $(-3.44$ & -0.78 & $-0.64)$ \\
\hline \multirow[t]{2}{*}{ III } & Upstream & 4.00 & ( 2.10 & 1.84 & $0.06)$ & 2.52 & $(2.52$ & - & - ) \\
\hline & Downstream & -6.38 & $(-3.13$ & -3.16 & $-0.09)$ & -7.51 & $(-6.66$ & -0.85 & -1 \\
\hline \multirow[t]{2}{*}{ IV } & Upstream & 3.82 & ( 2.04 & 1.78 & -1 & 2.90 & ( 2.02 & 0.88 & - ) \\
\hline & Downstream & -9.01 & $(-4.77$ & -4.24 & -1 & -10.39 & $(-9.76$ & -0.63 & - ) \\
\hline
\end{tabular}

and that the velocity from the lower layer is that for the lower section.

Not every water mass, summarized by the numerical method, is close to the value obtained by the measuring method, as can be seen in the third diurnal cycle. However, the sums of the total water masses moved upstream and downstream are almost the same for both methods in every diurnal cycle, suggesting good reproducibility of the scheme for current computation, although there might be some error in the relative difference in water levels. It is considered that a more exact measurement of water level variations is necessary for the current computation.

The net volume of water with salinity higher than $4 \%$ passing upstream during the second diurnal cycle was $2.5 \times 10^{6} \mathrm{~m}^{3}$, which could cover a bottom area of $30 \mathrm{~km}^{2}$ in Lake Shinji with a $0.08 \mathrm{~m}$ thick layer. SAWAMURA and KAMIYA (1991) reported the detailed movement of saline water in Lake Shinji just after the intrusion on 28 August 1990. It moved over the sill at the entrance and flowed down along the bottom slope as a density underflow with a speed of $0.1 \mathrm{~m} \mathrm{sec}^{-1}$. They did not continue the observations up to the formation of a stratified structure on the lake bottom. However, KAMIYA et al. (1996) estimated the nutrient release and accumulation in the bottom water under anaerobic circumstances after the formation of an intense stratified structure in the dry, hot summer of 1994. After the destruction of an intensely stratified structure by a typhoon on 29 September 1994, we observed vertical mixing followed by a bloom of Prorocentrum minimum which was found in the routine monthly survey. These results express the important role of meteorological events in the nutrient circulation in Lake Shinji, which begins with the intrusion of saline water from Lake Nakanoumi.

\section{CONCLUSIONS}

Our continuous month-long observation has confirmed the intermittent intrusions of saline water into Lake Shinji and clarified their mechanism as 
being related to astronomical and meteorological tidal conditions. A onedimensional numerical analysis using water level variations at both ends as boundary conditions approximately reproduced the intrusion phenomenon. This demonstrates the possibility of predicting intermittent intrusions of saline water, which lead to the formation of a two-layerd structure in Lake Shinji, using only the usual hydraulic monitoring at both ends of the Ohashi River. Therefore, destratification due to meteorological event should be the next subject of a hydrodynamical study concerned with the nutrient circulation produced in this coastal lagoon.

\section{ACKNOWLEDGEMENT}

This study would not have been realized without the support of the Kansai Research Organization for Hydrosphere Environments, and especially without the valuable assistance of Professor Ryohei TsuDA who was Secretary general of the organization. Therefore, this article is dedicated to Professor TSUDA in recognition of his contribution to the recent studies conducted in Lakes Shinji and Nakanoumi.

\section{REFERENCES}

Dronkers, K. K. (1969) : Tidal computations for rivers, coastal areas and seas. Proceed. ASCE, 95, HY1, 29-77.

FuJII, T. and S. NAGANAWA (1995) : Approximate solution of water level changes in brackish lakes. Jpn.J.Limnol. $56: 303-307$ (in Japanese).

GabRiELSON, J. O. and R. J. LUKATELiCh (1985): Wind-related resuspension of sediments in the Peer Harvey estuarine system. Estuarine, Coastal and Shelf Science, $20: 135-145$.

Ishitobi, Y., H. Kamiya, K. Hayashi and M. Gomyoda (1989) : The tidal exchange in Lake Shinji under low discharge conditions. Jpn. J. Limnol., $50: 105^{-113 .}$

IshitoBi, Y., H. KamiYa and H. Itogawa (1993): Tidal, meteorological and hydrological effects on the water level variation in a lagoon, Lake Shinji. Jpn. J. Limnol., $54: 69-79$.

JASINSKA, E. (1993) : Motion of salt water and associated fronts in tideless estuaries. Estuaries, $16: 53-67$.

Kamiya, H., Y. Ishitobi, T. Inoue, Y. NaKamura and M. Yamamuro (1996) : Origin of nutrients accumulated in the bottom water of Lake Shinji in summer. Jpn. J. Limnol., $58: 313-326$ (in Japanese).

KoJIMA, N. and T. MACHIDA (1987) : Computing methods with basic program I. Tokai Univ. Tokyo (in Japanese).

Ohtake, H., S. Kato and Y. Date (1984): The role of tides in removing phosphorus from Lake Nakanoumi, a coastal lagoon in Japan. Arch. Hydrobiol., 99, 4 : 443-462.

Pickrill, R. A., J. IRwin and B. S. Shakespeare (1981) : Circulation and sedimentation in a tidal influenced fjord lake: Lake McKerrow, New Zealand. Estuarine, Coastal and Shelf Science, 12:23-37.

Pugh, D. H. (1987) : Tides, surges and mean sea level, A handbook for engineers and scientists. John Wiley \& Sons, New York. 
River Bureau, Minist. Construction (1991) : Annual report on river flow in 1989. Kasen Kyokai, Tokyo (in Japanese).

Sawamura, K. and H. Kamiya (1991) : Movement of saline water in Lake Shinji, p. 195-202. Report on nutrient flux through Ohashi River. Shimane Prefecture (in Japanese).

UnCLES, R. J. and J. A. Stephens (1993) : The freshwater-saltwater interface and its relationship to the turbidity maximum in the Tamar Estuary, United Kingdom. Estuaries, $16: 126^{-141 .}$

Yu Isнітовг : Shimane Prefectural Institute for Public Health and Environmental Science, Nishi-Hamasada, Matue 690-0122，(石飛 裕：島根県衛生公害研究 所, 于 690-0122 松江市西浜佐陀町)

Hiroshi Kamiya : Shimane Prefectural Institute for Public Health and Environmental Science, Nishi-Hamasada, Matue 690-0122, (神谷 宏：島根県衛生 公害研究所, $\bar{T}$ 690-0122 松江市西浜佐陀町)

Koji Yoкочама: Disaster Prevention Research Institute, Kyoto University, Gokasho, Uji 611-0011，(横山康二：京都大学防災研究所， $\bar{T}$ 611-0011 宇治 市五ヶ庄)

Michio KumagaI : Lake Biwa Research Institute, 1-10 Uchidehama, Otsu 5200806,（熊谷道夫：滋賀県琵琶湖研究所， $\overline{\mathbf{T}} 520-0806$ 大津市打出浜 1-10)

Setsuo OKUDA : Okayama University of Science, 1-1 Ridaicho, Okayama 7000005，(奥田節夫：岡山理科大学， ₹ 700-0005 岡山市理大町 1-1)

(Received : 17 December 1997 ; Accepted : 30 July 1998)

\section{潟湖、实道湖への塩水侵入条件}

石飛 裕・神谷 宏・横山康二・熊谷道夫・奥田節夫

摘要

突道湖における塩分二層構造の形成過程を明らかにするために，中海と宾道湖を結ぶ大 橋川の最上流部において自記流速計と自動分析船を用いた一力月の連続観測を実施した。 斐伊川の低出水期に気象潮長期波動の上昇期と天文潮の一回潮が重なる場合に，中海塩水 の侵入が起きることが分かった。

大橋川における潮汐流と塩分輸送を，両端の水位と塩分をそれぞれの境界条件とする一 層を仮定した一次元モデルで計算した。二層の特幑が時々現れるにもかかわらずこれら は観測值と概略一致していた。穴道湖における成層構造形成の観点から，塩水侵入に続く 諸現象も述べた。 